\title{
AN ANALYSIS OF STUDENTS' DIFFICULTIES IN WRITING DESCRIPTIVE TEXT
}

\author{
Eni Ismayanti, Abdul Kholiq \\ eniismayanti97@gmail.com, abdulkholiq@unisla.ac.id \\ Program Studi Pendidikan Bahasa Inggris, Universitas Islam Lamongan
}

\begin{abstract}
This research aims to describe the students' difficulties in writing descriptive text and to find out the causes of students' difficulties in writing descriptive text. This research uses quantitative descriptive methods. The research subjects are X MIPA 6 students of SMAN 1 Sukodadi who had difficulties when writing descriptive text, the data of this research are the result of students' worksheet and the students' answer in interview. This research used documentation and interview to collect the data. Data reduction, data display and drawing conclusion was used to analyze the data. The result of this research shows that the students of X MIPA 6 have difficulty in writing descriptive text, the difficulties are difficulties in generic structure, difficulties in grammar, and difficulties in spelling. While the factors that cause the students' difficulties in writing descriptive text are lack of proficiency in the text production skills, lack of knowledge relating to the subject contents of the script to be written, and lack of interest in learning English.
\end{abstract}

Keywords: Students' difficulties, descriptive text

\section{INTRODUCTION}

English is international language that used by most of people in the world, including our country Indonesia. Goodwyn \& Branson (2005:1) states English is vitally important and typically described as the most important of all school subjects, principally because reading, writing, speaking and listening are needed to a greater or lesser degree in every other school subject, and life. Most of people know about English language, it has an important part in Indonesian education. English has been tought from elementary school until university. If someone is understanding well about English, they will able to understand about a lot of information and knowledge.

Understanding about English as a foreign language is begun with English learning activities through learning the skills properly. It is very important for students to mastering English in all skill, such as listening speaking, reading, and writing. In this case, the researcher is going to focus on writing. Writing is one of the English skills that must be mastered by the English language learners.
According to Nation (2009:113) Writing is an activity that can usefully be prepared for work in the other skills of listening, speaking and reading. This preparation can make it possible for words that have been used receptively to come into productive use. Writing is also considered as the indicator toward the student success in learning English. Since writing is productive skill, it also helps the students to develop their ability in expressing what they feel and think. Writing, speaking, and listening are communication skills that are important in all subject areas in the curriculum. This is because the students should be able to communicate in the target language in spoken and written language.

To make good writing, it needs to follow some steps. According to Harmer (2004:4) the process of writing has four steps, they are: 1) planning; 2) drafting; 3) editing; 4) final version.

In planning, before start to write, the writer will try and decide what it is they are going to write. For some writers this may involve making detailed notes. 
When planning, writers have to think about three main issues. In the first place they have to consider the purpose of their writing. The Second is experienced writers think of the audience what they are writing for. The last, the writers have to consider the content and the structure.

In drafting, the writers write down on paper what the ideas that they gets from their mind. The writers can refer to the first version of a piece of writing as a draft. As the writing process proceeds into editing, a number of drafts may be produced on the way to the final version.

In editing (reflecting and revising), when writer have produced a draft they usually read trough what they have written to see where it works and where it doesn't. Perhaps the order of the information is not clear, something in written is ambiguous or confusing.Reflecting and revising are often helped by other readers who comment and make suggestions.

In final version, once writers have edited their draft, making the changes they consider to be necessary, they produce their final version. This may look considerably different from both the original plan and the first draft, because things have changed in the editing process. But the writer is now ready to send the written text to the reader.

In classroom practice, most of students think that writing is difficult. It is because in writing there are some important components such as vocabulary, spelling, punctuation, and grammar. Writing text is a challenge for students, especially for the tenth grade students of senior high school, who is learning about various kinds of text, writing descriptive text is one of it. The students need to pay more attention in detail object that is described with the correct grammar.

Descriptive text is a general text where it can be included to another text. Accorrding Husna (2013) descriptive text is a kind of writing that consists of description characteristics and definition of object or something. While, Gerot and Wignel (in Mardiayah, 2013) state that descriptive text has purpose to describe particular thing, people or place which show the reader about physical appearance of something clearly. Based on definition of descriptive text above, it can be concluded that descriptive text is a text which describe people, place and things physically by their appearance.

Mastering descriptive text helps the students to make another kind of text such like narrative text, recount text and report text. For example in narrative text when the students want to make the readers interested in it they must be able to make the text with a good detail, it demands the students to explain something in details. According to Gerot and Wignel (in Mardiayah, 2013) the generic structure of descriptive text are identification and description. In identification is identifies the subject to be described. The identification usually stated in the first paragraph to introduce the reader what the topic to be described in the next paragraph. In description, the writer explain about the subject in detail. It uses to support identification.

According to Sudarti \& Grace (in Yenita, 2014) there are several language future use in descriptive text, they are: Using simple present, simple present tense is the activity happen in daily life, and the habitual activity. . However, sometimes it uses past tense if the thing to be described doesn't exist anymore. Use linking verb. Use adjective and compound adjectives and use of degree comparison

There are still many students who are not able to write a descriptive text. Muhammed (in Nasser, 2018) states that the students may face many writing difficulties and problems at different stages of their learning. According to Novita (2017) in her research, she state that the students showed that they have some difficulties in writing descriptive 
text. They are: 1) generic structure; 2) grammar; 3) spelling.

The difficulties on generic structure of descriptive text consist of describing object in detail (Novita, 2017). The students have to organize their ideas into good paragraphs, the students have to make their writing readable. To write a descriptive text, the students can organize their ideas by identifying the topic and give the descriptions about the topic (Husna, 2013).

According to Husna (2013) grammar difficulties will influence certain patterns of how words are put together to form the correct sentences. The students had some difficulties in using simple present tense. The students made some mistakes when they elaborated the idea in simple present tense. It's make the students difficult to write descriptive text.

Farooq (2012) state that spelling is a skill of identifying a word in spoken or written mode. Spelling and decoding skills are closely linked, students who suffer from spelling problems need to memorize the spellings of the words.

Another cases that the researcher found while doing teaching practice program, Senior High School students especially the tenth grade, the students did not understand well about what they should write and describe. The students can't describe things, places, and a person in detail because they do not have any ideas when they are asked to describe them. Students are not interested in learning writing. They are lazy and bored if the teacher ask them to write something even it just writes a descriptive text.

There are some of the students who can't make descriptive text. Some of them open their smart phone to search the example of descriptive text. Without reading it first, the students just copy it so, some of them do not understand about the purpose and contain of the text. They can't make the descriptive text in their own writing, so they copy paste it from internet.
The students also can't express their idea, so the students just copy it from internet. The students also show some gesture that reflect that they was have difficulties in writing descriptive text and there are some students, who just walk around to see another students duty.

The students difficulties can be caused by some factor,according to Graham \& Harris (in Glynn, 2006:98) writing difficulties may in large part, be the result of three factors, they are:

Lack of proficiency in the text production skills that is frequent errors in spelling, the use of upper and lower case, and punctuation. The amount of attention that has to be expended on lower-level skills is thought to interfere with higherorder skills of planning and the generation of content (MacArthur and Graham in Wearmouth, 2006:252).

Lack of knowledge relating to the subject content of the script to be written, Wray (in Wearmouth, 2003:252) suggests that the actual task is important, and that the writer reflects on the different genre, and the structure and accessibility of the writing for the reader and how the reader may be guided through the writing. Knowledge of the process is also important for metacognition and reflection. Lack of effective strategies in planning or revising text, Graham and Harris (in Glynn, 2006:98) adopt a cognitive approach to supporting students experiencing writing difficulties because this approach emphasizes the component processes of writing production which can then be focused upon individually.

Based on the explanation above, the research is the interested in conducting the research study to investigate the students' difficulties in writing descriptive text and the cause of the students' difficulties in writing descriptive text. furthermore, this research is conducted with the purpose to know the difficulties that students have and to knowing the 
factor that cause the students' difficulties in writing descriptive text.

\section{METHOD}

In this research, the researcher uses a qualitative descriptive method. The researcher uses a qualitative descriptive method because the researcher tries to describe each type of students' difficulties in writing descriptive text and the factors that cause the students' difficulties in writing descriptive text in detail and clearly without numerical data.

The subject of this study is the tenth grade students of SMAN 1 Sukodadi. Especially X MIPA 6 class which consist of 35 students, 12 male and 23 female.

In this research documentation and interview uses as data collecting technique. In documentation, the researcher asks the students to make a descriptive text about their family. They can choose one of them, for example, their mother, father, or sister, etc. In interview, each respondent is asked the same question, and the researcher writes it down. The researcher does the interview with some of the students of X MIPA 6 as an informant by asking some questions related to the students' difficulties in writing a descriptive and the factor that caused the difficulties.

Documentation checklist and question list was used as instrument. The documentation checklist is used in this research, the aim of documentation checklist is to document the students' worksheet. Question list is used in this research as an instrument to interview the students. The researcher makes DISCUSSION

\section{The Students' Difficulties in Writing Descriptive Text}

1. The Students' Difficulties in Writing Descriptive Text on Generic Structure

There are some of the students that have difficulties in generic structure, the data were shown below:

\section{My Father}

My father is handsome. He likes to cook. He is always there when I like and grieve. He was the one who always supported me and obeyed my will. As head of the family he has fulfilled his duties and is always there for his family. (S4) some questions to interview the students that have difficulties in writing descriptive text.

After collecting the data, then the data analysis is performed to analyse all the data that has been obtained. In this research used qualitative descriptive research. According to Miles and Huberman in Sugiyono (2016:246) there are four activities in data analysis, they are: data reduction, data display, and conclusion drawing/verification

Data reduction, after the students' worksheet is collected, the researcher chooses the students' worksheets that show the students have difficulties in writing descriptive text, then it is analysed by the researcher. Then the researcher chooses some students that have difficulties in writing descriptive text, the students are interviewed by the researcher to find out the factors that cause the students' difficulties in writing descriptive text.

Data display, in this step the researcher analysed the students' worksheet about descriptive text, to find out what are the difficulties that students have, when they writing descriptive text about their family and analysed the students' answer in interview, to find out the factors that cause the students' difficulties in writing descriptive text about their family.

Conclusion drawing or verification, the researcher concludes the students' difficulties in writing descriptive text and the factors that cause the students' difficulties in writing descriptive text.

The student S4 wrote a descriptive text about her father. She described how her father looked likes, what he liked to do and how his personality was.

From the descriptive text above, the researcher found that the students had difficulties in generic structure. The generic structure of descriptive text consisted of two paragraph, it was identification and description. But the student S4 just made one paragraph. In the first paragraph, the student should introduce or identify the character, in this 
case, the topic was her father, but she immediately described about her father without introducing or identifying him first. In the second paragraph, the students should describe the character, in this case, the topic was her father. The student already described her father, but she didn't describe him in detail. The other data were shown below:

\section{My Mother}

My mother is angry, she is very shy. My mother is disciplined, my mother's skin is white, her hair is long. I love you mom. (S20)

Same as the data before, the student S12 had difficulties in generic structure. She wrote a descriptive text about her mother, same as student S4 the student S12 did not introduce or identify the character first, the topic was her mother, she immediately described about his mother without introducing or identifying her first. The student S12 should introduce the character in the first paragraph. The student S12 could write when and where her mother was born, her weight and height. Then, in the next paragraph, the student S12 should describe the character in detail, for example, she could write about her mother's hobby, habit, etc. The descriptive text written by student S12 is too short. Not only that, the student S12 not introduced the character clearly and she did not describe the character in detail.

\section{My Father}

My father is lovely, he is hard work people. He is smart and can do. My father name is Kaselan. He like eat a plate of fried rice and like drink a cup of coffee. (S30)

The student S30 wrote a descriptive text about his father. He was wrote about how his father personality and his name. The text was consist of one paragraph and it is too short.

From the descriptive text above, the researcher found that the students had difficulties in generic structure. In the first paragraph the student should introduce or identify the character, this case, the topic was his father, but he immediately described about his father without introducing or identifying him first. In the first paragraph, the student should introduce the character, the student could write his father's height, weight, etc. In the second paragraph, the student should describe the character in detail, for example the student could write about his appearance.

\section{The Students' Difficulties in Writing} Descriptive Text on Grammar

In the grammar, it consists of two topic, the first is arranging the word that includes noun, pronoun, verb, adjective, adverb, preposition, etc. and the second is arranging the sentence (tenses) the researcher only focuses to analyze arranging word and arranging sentence, but in arranging sentence the researcher only focuses on simple present tense.

1) The Students' Difficulties in Writing Descriptive Text on Arrange the Word

- The students' difficulties in writing noun

"I have a one father" (S5)

"I have my sister" (S32)

From the data above, the researcher found that students had difficulties in writing noun, the two sentences above were singular noun, so it must use " $a$ " or " $a n$ ", but the students didn't understand and made an error. So, the two sentences above should be changed into "I have a father" and "I have a sister".

- The students' difficulties in writing pronoun on writing "he" which supposed to be "she"

"My mother is very good, always teach me discipline, he has a short haired" (S8)

"My mother was a hero, because he was always accompany me." (S6) 
"She never complained when he educated me" (S16)

From the data above the researcher found that the student had difficulties in writing pronoun. The word "he" it should be changed into "she", because my mother is a women so it should be used personal pronoun "she".

The students' difficulties in writing pronoun on writing "she" which supposed to be "he"

"My father name is Zen Ansori.

She like coffee in warung coffee" (S17)

"My father is a soldier. She work in Madura Island, Sampang district." (S5)

"My father is my hero, because she is very good for me." (S22)

"He don't mad to me even I do a foult. But, she tell me how to do a good thing" (S28)

From the data above the researcher found that the student had difficulties in writing pronoun. The word "she" it should be changed into " $h e$ ", because, my father was a men so it should be used personal pronoun "he".

The students' difficulties in writing pronoun on writing "her" which supposed to be "she"

"Her fourteen years old. Now her 9 junior high school. Her school in the SMPN 1 Sukodadi" (S32)

"Her like drink a bottle of avocado juice. Her like play game." (S32)

From the data above, the researcher found that the student had difficulties in writing pronoun. The word "her" it should be changed into "she", because the word "her" was took place of noun and used as the object of the verb in a sentence. The word "she" was took place of noun and used as the subject of the verb in a sentence.
The students' difficulties in writing pronoun on writing "her" which supposed to be "his"

"I have a brother, her name is Eriko." (S7)

From the data above the researcher found that the student had difficulties in writing pronoun. The word "her" it should be changed into "his". Because, the word "her" was used for a subject woman, and the word "his" was used for subject man. In the sentence above it's about the student's brother, the brother was a man, so the word "her" should be changed into "his".

2) The students' difficulties in use determiner

"Then she take a bath and cleaning a bedroom" (S3)

"She is usually clean house" (S26)

"He always understand the condition and needs of his children" (S31)

From the descriptive text above, the researcher found that the students had difficulties in used determiner. The students should add word "the" before a noun, because the students was wrote about a certain thing, it was house, needs, and bedroom. So, the sentences above should be changed into "she usually cleans the house", "he always understands the condition and the needs of his children", and "Then she takes a bath and cleaning the bedroom".

3) The students' difficulties in preposition

Preposition is usually followed by a noun or pronoun. The students' difficulties in preposition are showed below:

The students' difficulties in writing preposition on writing "on" which supposed to be "in".

"She was born on Lamongan" (S3)

From the data above, the researcher found that the students had difficulties in preposition "in". The student 
S3 should use "in" not "on". Because "in" was used to show a general place not specific, and "on" was used to show a location that was slightly more specific than "in". Lamongan was general and not specific place, because Lamongan was large and has some areas or district. So the data above should use "in".

The students' difficulties in writing preposition on writing "on" which supposed to be "at".

"She up on 04.03" (S3)

From the data above, the researcher found that the student had difficulties in preposition, especially in used "at". The student S3 should use "at" not "on". Because the data above was showed a specific time, so the students should use "at" to show the time.

The students' difficulties in writing preposition on writing "of" which supposed to be "for".

"He can be a father and best friend of his children" (S31)

From the data above, the researcher found that the student had difficulties in preposition. "of" was used to show the ownership, reference, and numbers, while "for" was used to show the function or the used of an object or other thing. The data above was showed the used of friend, so the word "of" it should be cahnged into "for" to show the function of friend.

The students' difficulties in writing preposition on writing "to" which supposed to be "for"

"She usually making breakfast to family" (S26)

"I know he work hard to me" (S28)

"My mother was a hero to me" (S6)

From the data above, the researcher found that the students had difficulties in preposition especially in used "for". The word "for" was used to show the function or the used of an object or other thing, while "to" was used as a pointer to an object such as place, a person or something that move, to indicate the boundary or end point, and to show a relation between clauses. The data above was showed the function of the object (me, family), so the word "to" should be changed into "for".

4) The Students' Difficulties in Writing Descriptive Text on Use Simple Present Tense

Simple present tense is used to state fact, activity or repetitive activities. In a way, this tense is the easiest one if it compared to other tense. Positive sentence in simple present tense is using verb 1 or to be / is / am / are. If the subject is a single third person (he, she, and it), verb 1 must be added by suffix $-\mathrm{s} /$-es. For example he eats, she goes, it seems, etc. The formula of simple present tense is:

1) Positive sentence:

- $\quad$ Subject + verb 1 (+s/es) + object/adverb

- $\quad$ Subject + to be (is/am/are) + adjective/adverb

2) Negative sentence

- Subject + do/does + not + verb $1+$ object/adverb

- Subject + to be (is/am/are) + not + adjective/adverb

3) Interrogative sentence

- Do/does + subject + verb $1+$ object/adverb?

- To be (is/am/are) + subject +adjective/adverb?

The students' difficulties in simple present tense is shown below:

3. The students' difficulties in grammar on writing "was" which supposed to be "is"

"My father was special in my life" (S1)

"He was the one who always support me" (S4)

"My mother was a hero to me, because she was always accompany me" (S6)

"My mother was a special woman in my life" (S24) 
"My father height was around $170 \mathrm{~cm}$ and his weight was around $60 \mathrm{~kg}$ his hair was black and short." (S31)

From the data above, the researcher found that the students had difficulties to use simple present tense in using to be. Simple present tense uses to be "is, am, and are". So the data above should use to be "is" not "was".

1). The students' difficulties in arrange positive sentence of simple present tense

"She with my grandmother in home" (S3)

"His name Nur Efendi" (S5)

"She a hero in the family" (S19)

"She usually making breakfast to family" (S26)

From the data above, the researcher found that the students had difficulties in use to be "is". The students did not use to be as in the formula. The formula is Subject + to be (is/am/are) + adjective/adverb. So, after the subject, the students must add to be "is" in their sentence. For example the sentence that written by S5 and S19 "His name Nur Efendi" this sentence should be changed into "His name is Nur efendi", and "She a hero in the family" should be changed into "She is a hero in the family". Another difficulties were shown below:

"He like eat a plate of fried rice and drink a cup of coffee" (S30)

"My sister like a plate of fried rice, cupcake and her like drink a bottle of avocado juice." (S32)

"Her like play game, usually my sister play game with me" (S32)

From the data above, the researcher found that the students had difficulties in arranging the word. The students did not add $-\mathrm{s}$ or -es after verb 1 as in the formula. The formula is Subject + Ver 1 (+s/es) + object/adverb. So, after the verb 1 , the students must add to be "s" or "es" in their sentence. For example the sentence that written by S30 "he like eat a plate of fried rice and drink a cup of coffee", the word "like" is as verb 1 , so it should be added by - s. So, the sentence should be changed into "he likes eating a plate of fried rice and drinks a cup of coffee".

2). The Students' Difficulties in Writing Descriptive Text on Spelling

The difficulties in spelling in this research is when the students makes an error in writing a word. The difficulties are shown below:

"He is fery handsome" (S1)

"My mom is verry beautiful" (S19)

"My father veri handsome" (S20)

"He woks like as captain" (S5)

"She is a bautiful girl" (S16)

The data above are show that the students had difficulties in spelling word. The sentence "He is fery handsome" written by S22, the word 'fery' it should be changed into "very". The sentence "My mom is verry beautiful" written by S19, the word "verry" it should be changed into "very". Same as before, the sentence "My father veri handsome" written by S20, the word "veri" it should be changed into "very". The sentence "He woks like as captain" written by S5, the word "woks" it should be changed into "works", and the sentence "She is a bautiful girl" written by S16, the word "bautiful" it should be changed into "beautiful".

Based on the result of data analysis above, the researcher found that the students had difficulties in all point. The students' difficulties was known from the student's worksheet, the researcher found that the students had difficulties in generic structure, grammar and spelling. The students who had difficulties in generic structure did not know how to make a good descriptive text, the students only made a simple descriptive text, they did not describe their family in detail. The students who had difficulties in grammar didn't know how to make a correct sentence and they were confused in using simple present tense. The students who 
had difficulties in spelling they were made an error when they writing an English word. So, what Novita (2017) said before was same with the students' difficulties which researcher found. The difficulties were in generic structure, grammar, and spelling.

\section{The Factor that Cause the Students' Difficulties in Writing Descriptive Text}

The researcher used Bahasa to interview the students, then the researcher translated the interview into English. Based on the interview, the researcher found the factors that cause the students' difficulties in writing descriptive text are:

1. Lack of Proficiency in the Text Production Skills

Lack of proficiency in the text production skills was one of the factors that caused the students' difficulties in writing descriptive text. There were some students that said the cause of their difficulties was lack of proficiency in text production skills. The data from interview were shown below:

The researcher: "what are the causes that make you difficult in writing descriptive text?"

S17: "I don't understand how to arrange a good sentence in English miss, and also because I'm not interest in learning English."

S31: "I don't understand about grammar miss, the teacher not explain about it."

The student S17 said that she didn't understand how to make a good sentence in English, the student S31 said that she didn't understand about grammar. So it was the factor that caused her difficulties in writing descriptive text. The other data from interview were shown below:

S8: "I am confuse to write a good sentence in English miss. The material about descriptive text is also difficult for me miss."
S32: "I don't understand the grammar and I don't know how to make a good sentence in English."

S22: "The problem is because I don't understand how to make a good sentence in English miss, so I think that is the cause of my difficulties miss."

S3: I rarely study English and I don't understand how to make a correct sentence in English."

S19: "I don't understand the grammar, the material of descriptive text and I don't like English lesson miss."

S28: "The problem is because I don't know well about grammar miss, it's too hard."

Form the data above the students said that the cause of their difficulties was because they don't understand about grammar and don't understand how to arrange correct sentence. It can be said that the cause of their difficulties was lack of proficiency in the text production skill. Because grammar and how to arrange the sentence are included in the text production skill. Mastered grammar was important, if the students understood well about grammar they be able to make a good descriptive text. The students who said that the cause of their difficulties was grammar they said that the teacher did not explain the grammar.

2. Lack of Knowledge Relating to the Subject Content of the Script to Be Written

Lack of knowledge relating to the subject content of the script to be written was one of the factors that caused the students' difficulties in writing descriptive text. There were some students said that this was the factor that caused their difficulties. The data from interview were shown below:

The researcher: "what are the causes that make you difficult in writing descriptive text?" 
"S5: "The problem is because I forget the material of descriptive text miss."

S8: "I am confuse to write a good sentence in English miss. The material about descriptive text is also difficult for me miss."

S19: "I don't understand the grammar, the material of descriptive text and I don't like English lesson miss."

The data above were shown that the cause of the students' difficulties was didn't understand about the material of descriptive text. It could be said that the cause of their difficulties was lack of knowledge relating to the subject content of the script to be written. Because the subject in this case was descriptive text, and the student said that they didn't understand about the material of descriptive text and they said that the material of descriptive text was difficult to understand.

3. Lack of Interest in Learning English

Lack of interest in learning English was one of the factors that caused the students' difficulties in descriptive text. Some students said they didn't interest in learning English. The data were shown below:

\section{S16: "I'm not interest in learning English."}

The students above was said that they didn't interest in learning English. There are some students have the same answer as the students above. The data were shown below:

S1: "The problem is because I don't like English miss, it's too difficult".

S20: "Because I don't like English lesson miss."

S30: "Because I'm not interested in learning English."

S26: "I'm not interested in English."

S17: "I don't understand how to arrange a good sentence in
English and I'm not interest in learning English."

From the data above the researcher found that the factors that caused the students' difficulties was not interested in learning English. Most of the students said that they didn't interest in learning English. Because, the students think that English was difficult to learn. Not only that, they said that writing in English is also difficult.

Based on student's interview, the researcher only found two factors that same with three factors above, and the researcher found one another factor. The two factors that same as Graham \& Harris (in Glynn, 2006:98) said were lack of proficiency in the text production skills and lack of knowledge relating to the subject content of the script to be written. The students said that the caused of their difficulties were they didn't understand how to made a correct descriptive text and they didn't understand about grammar. The other factor that researcher found was lack of interest in learning English. Most the students of X MIPA 6 said that the caused of their difficulties was because they didn't interest in learning English. They said that English was difficult to learn.

\section{CONCLUSION}

The students' difficulties in writing descriptive text at tenth grade students of SMAN 1 Sukodadi are: 1) The difficulties in generic structure. It's mean that the student can't make a descriptive with correct generic structure. 2) The difficulties in grammar. It's mean that the student can't arrange the word correctly and can't arrange simple present tense sentences correctly. 3) The difficulties in spelling. It's mean that the students can't write the correct word in English.

The factor that caused the students' difficulties in writing descriptive text at tenth grade students of SMAN 1 Sukodadi are: 1) Lack of proficiency in the 
text production skills. It is mean the student is lack of the proficiency in grammar and lack of the proficiency of how to arrange correct word and sentence. 2) Lack of knowledge relating to the subject content of the script to be written.

\section{REFERENCES}

Farooq, M. S., Uzair-Ul-Hassan, M., \& Wahid, S. S. (2012). Opinion of Second Language Learners about Writing Difficulties in English Language. A Research Journal of South Asian Studies , 27 (1): 183194.

Glynn, T., Mere, J. W., \& Berryman. (2006). Supporting Students with Literacy Difficulties . New York: Open University Press.

Goodwyn, A., \& Branson, J. (2005). Teaching English. New York: Routledge Falmer.

Harmer, J. (2004). How to Teach Writing. Essex: Pearson Education Limited.

Husna, L., Zainil, \& Rozimela, Y. (2013). An Analysis of Students' Writing Skill in Descriptive Text at Grade X1 Ipa 1 of MAN 2 Padang. Journal English Language Teaching (ELT), 1 (2): 1-16.

Mardiyah, D., Saun, S., \& Refnaldi. (2013). The Second Grade Students' Ability in Writing a Descriptive Text at SMP N 1 Canduang. Journal of English Language Teaching, 1 (2): 281-290.

Nasser, S. M. (2019). Iraqi EFL Students' Difficulties in Writing Composition: An Experimental Study.
It is mean that the students not understand well about the material of descriptive text. 3) Lack of interest in learning English. It is mean that the students not interest in learning English at school.

International Journal of English Linguistics, 9 (1) : 178-184.

Nation, I. S. (2009). Teaching ESL/EFL Reading and Writing. New York: Routledge.

Novita, C. S. (2017). An Anlysis of Students' Ability and Diffulties in Writing Descriptive Tetx (A Study at SMA Negeri Bunga Bangsa, Nagan Raya). Banda Aceh: English Education Department Faculty of Tarbiyah and Teacher Training ArRaniry State Islamic University Darussalam .

Sugiono. (2016). Metode Penelitian Kuantitatif, Kualitatif, dan $R \& D$. Bandung: Alfabeta.

Wearmouth, J., Soler, J., \& Reid, G. (New York). Meeting Difficulties in Literacy Development. 2003: Routledge Falmer.

Wijayatiningsih, T. D., \& Wardhani, M. Y. (2014). Genre-Based Analysis of Students' Descriptive Text in The Tenth Grade Students of MAN 2 Semarang. Journal of English and Education, 4 (1): 43-47.

Yenita, H., Tanjung, F., \& Septy, A. P. (2014). Teaching Writing Descriptive Text By Using Collaborative Technique. Journal of Language and Teaching, 3 (5): 1-8. 